\section{Beroepsziekten in cijfers 2020}

André Weel

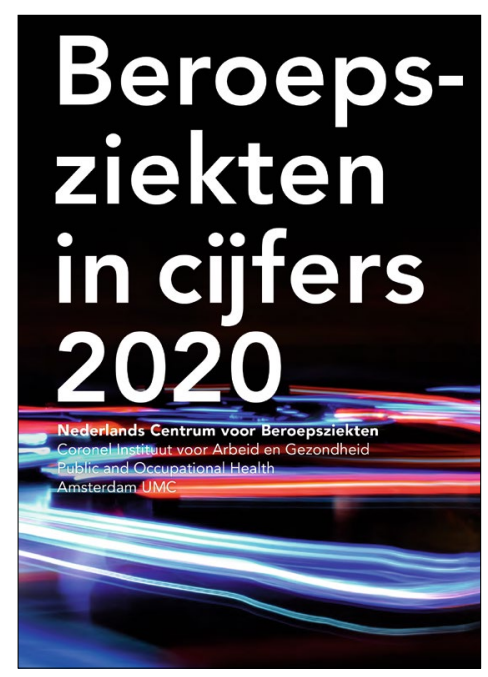

De jaarlijkse uitgave van het Nederlands Centrum voor Beroepsziekten is uit! Sinds 2000 krijgen we elk jaar een fraai overzicht van alle beroepsziektemeldingen door Nederlandse bedrijfsartsen. Een mooi aanknopingspunt voor preventie! Anders dan de titel doet vermoeden gaat deze nieuwe editie over de in 2019 gemelde beroepsziekten. Toch staat er een hoofdstukje in over de meldingen van COVID-19. Die zijn uiteraard allemaal van 2020. Vanaf maart 2020 kun je COVID-19 als beroepsziekte melden. Daarover straks meer.

Sinds 2015 daalt het aantal meldingen per jaar gestaag. In 2019 zijn er 3691 beroepsziekten gemeld. Die zijn afkomstig van 404 bedrijfsartsen. Dat is slechts één vierde van de Nederlandse bedrijfsartsen. Maar dit aantal is gelukkig niet gedaald.

Met die 3691 beroepsziekten kun je geen incidenties berekenen, omdat je niet weet hoeveel werknemers de 'populatie at risk' precies omvat. Dat kan wel met het Peilstation Intensief Melden. Hieraan doen 156 gemotiveerde bedrijfsartsen mee. Hier gaat het om uitgebreide meldingen van beroepsziekten uit een werknemerspopulatie waarvan we de aard en de omvang weten, zodat de incidentie nauwkeurig kan worden geschat.

Het BIC is zeer overzichtelijk. Beroepsziekten zijn per orgaansysteem in afzonderlijke hoofdstukjes samengebracht. Elk hoofdstukje vat de informatie van het betreffende orgaansysteem samen in zes pictogrammen. Voor wie liever geen tekst leest is dit een effectieve manier van informatieoverdracht. De pictogrammen betreffen de aantallen meldingen en meldende artsen, de verdeling van de beroepsziekten naar leeftijd en geslacht, de diagnose, de risicofactoren, de duur van de arbeidsongeschiktheid bij de gemelde gevallen, en de top 3 van sectoren waar deze ziekten voorkomen.

Psychische beroepsziekten zijn het meest gemeld: maar liefst 2222 in 2019. Driekwart hiervan betreft overspanning en burn-out. Dit is dan ook de meest gemelde beroepsziekte.

Lawaaislechthorendheid is de laatste jaren flink gedaald: van 2422 meldingen in 2015 naar 128 in 2019. Dat betekent niet dat het ook minder optreedt. We moeten deze afname toeschrijven aan het verdwijnen van de Stichting Arbouw in 2016, met als gevolg daarvan het stoppen van de systematische opsporing bij het PAGO. Wie niet zoekt zal niet vinden!

Bij longen en luchtwegen voert het werkgerelateerde astma de lijst aan. Bij neurologische aandoeningen is dat het carpaletunnelsyndroom. CTE (chronische toxische encefalopathie) is de laatste twee jaar niet meer gediagnosticeerd. Preventie heeft gewerkt!

Beroepskankers zijn negenmaal gemeld. Dit is slechts een 0,5 procent van het geschatte aantal op basis van de literatuur. Uit andere bronnen weten we dat er jaarlijks nog ruim 600 nieuwe gevallen van mesothelioom in Nederland optreden. Vrijwel altijd gaat het hierbij en bij andere vormen van beroepskanker om mensen die met pensioen zijn. En die komen niet meer bij een bedrijfsarts.

De ziekte van Lyme is de meest gemelde specifieke infectieziekte met 14 beroepsziektemeldingen in 2019. En dan COVID-19. Wanneer mag je hierbij spreken van een beroepsziekte? Daartoe heeft het NCvB een Stappenplan registratie Corona Virus Ziekte 2019 als beroepsziekte R605 opgesteld. Tot 1 augustus 2020 is COVID-19 732 maal gemeld, meest bij personeel in verpleeg- en verzorgingshuizen.

U vindt BIC-2020 ook op internet: https://www.beroepsziekten.nl/content/beroepsziekten-cijfers-2020 